\title{
Physical Education Teachers' Using of Teaching Styles Levels and Their Perceptions Towards Styles in Public and Private Schools in Turkey
}

\author{
Mehtap Yıldız ${ }^{1, *}$ \& Ömür Fatih Karakullukçu ${ }^{2}$ \\ ${ }^{1}$ Physical Education and Sports Department, Faculty of Education, Necmettin Erbakan University, Konya, Turkey \\ ${ }^{2}$ President of School Sports Federation of Turkey, Ankara, Turkey \\ *Correspondence: Physical Education and Sports Department, Faculty of Education, Necmettin Erbakan University, \\ Konya 42090, Turkey. E-mail: yildizmehtap77@gmail.com
}

Received: June 23, 2019

Accepted: July 21, 2019 Online Published: August 15, 2019

doi:10.5430/wje.v9n4p41

URL: https://doi.org/10.5430/wje.v9n4p41

\begin{abstract}
The purpose of this research is to determine the using of teaching styles of physical education teachers in public and private schools in Turkey and related to these styles to find out the value perceptions. The research was performed out with survey model. The research group consisted of simple random sampling method based on the probability sampling methods 2017-2018 Academic Year in Turkey in Kayseri province 109 of them work at public schools and 47 of them work at private schools and totally 156 physical education teachers. As the data collection tool the "Physical Education Teachers Use of Teaching Styles and Perceptions of Styles Questionnaire", developed by Kulinna and Cothran (2003) and adapted to Turkish by Ince and Hunuk (2010), was used in the research. In the analysis of the data the Arithmetic mean, standard deviation, independent t-test and variance analysis tests were used for repeated measurements. The meaningfulness level was adopted as $\alpha=0.05$. As a result of the research, it was determined that physical education teachers in public and private schools use teaching centered teaching styles.
\end{abstract}

Keywords: physical education teacher, teaching styles, public school, private school

\section{Introduction}

Teaching methods and techniques are a vital part of the teaching and learning process. These methods are selected and applied by the teachers during the applications in which the aims are gained as behaviors to the students. The teaching method applied is the way the teacher consciously chooses and follows in the classrooms. When choosing methods, teachers have to consider their own characteristics, physical facilities, time, cost, size of the group of students, the characteristics of the subject and the qualities to be developed in the student (Taspinar, 2010). A good method in teaching is the one that is general, but enriched by the teacher's personal experiences. In a good teaching method, there should be some things included; being objective, conform to teaching principles, being easy to apply and economical, and allow the teacher to make personal discoveries and contributions (Karaagacli, 2005).

The most important part of teaching planning for a physical education teacher is to decide which teaching method can teach a skill. A good knowledge of teaching methods will lead teachers to present their knowledge and skills correctly and students to gain appropriate behaviors (Pangrazi, 2007). Jenkins et al. (2006) specified that using effective teaching methods in physical education courses causes students to develop positive attitudes towards the course. Tessier et al. (2010) determined that the personality traits of physical education teachers and the autonomy that the students recognized in the lessons increased the participation and motivation of the students. Sanchez et al. (2012) stated that high school students feel better in terms of physical and mental aspects in the inclusion style than the command and practice style.

In 1966, Musska Mosston published the book "Spectrum of Teaching Styles" by expanding the concept of methodology that included teaching strategies and styles (Metzler, 2017). In this book, in addition to the teaching centered Command (A) and Practice (B) styles that teach in physical education class, more learner-centered Reciprocal (C), Self-Check (D), Inclusion (E), Guided Discovery (F), Convergent Discovery (G), Divergent Production (H), Learner's Individual Designed Program (I), Learner Initiated (J) and Self-Teaching (K) styles are available (Mosston and Ashworth, 2002). According to Chatoupis (2010) the aim of using A-E styles in teaching is 
to increase the knowledge and skills of special knowledge. These styles are reproduction-based styles. Once the teacher has determined the subject of the lesson, he explains the teaching style, specifies the learning conditions and defines the criteria. Feedback during teaching is clear and corrective. However, F-K styles are production-based styles. The student is invited to discover new information. In some styles, even teachers may have to strive to produce new ideas. The use of these styles contributes to students' emotional development as well as their cognitive processes such as problem solving, discovery, comparison and synthesis (Chatoupis, 2010). Each of the styles shows the instructional control and decision making of a course, as well as the direction, activities, speed and interaction of the participants during the course. Besides this, Mosston explains how each style can contribute to students' mental, affective, and psychomotor development (Christenson and Barney, 2010). According to Mosston, teaching behavior involves a number of decision-making processes. Teaching style is the decisions made by teachers and students on a specific subject (Tamer and Pulur, 2001). Mosston and Ashworth (2002) presented the teaching styles in two main teaching approaches: presentation and invention. There is a transition from teacher-centered approaches to learner-centered approaches in this 11-style range.

The constructivist approach prepared by the philosophy of middle and high school physical education course in Turkey are expected to be used more learner-centered styles based on the new curriculum that is used by physical education teachers. However, it is also known that there is research that physical education courses that have different teaching styles increase the motivation of the students (Papaioannou and Kouli, 1999).

The purpose of this research is to specify using of teaching styles of physical education teachers in public and private schools in Turkey and related to these styles to find out the value perceptions.

\section{Method}

\subsection{Research Model}

The research was carried out with survey model. Surveying researches aim to explain the current situation as well as to review all current or historical data related to the object (Simsek, 2012).

\subsection{Research Group}

The research group consisted of totally 156 physical education teachers in Kayseri province; 109 of them work at public schools and 47 of them work at private schools for 2017-2018 Academic Year in Kayseri in Turkey. The research group was formed according to the simple random sampling method which is one of the probabilistic sampling methods. This method is the type of sampling in which each member of the population has an equal chance of being selected (Fraenkel, Wallen, and Hyun, 2006). The personal characteristics of the physical education teachers in the research group are given in Table 1.

Table 1. Personal Characteristics of Physical Education Teachers that Work at Public and Private Schools

\begin{tabular}{llllllll}
\hline Physical Education & Personal & \multicolumn{2}{c}{ Public School } & \multicolumn{2}{c}{ Private School } & \multicolumn{2}{c}{ Total } \\
\cline { 2 - 7 } Teachers' & Characteristics & f & \% & f & \% & f & \% \\
\hline \multirow{2}{*}{ Gender } & Male & 71 & 65,1 & 27 & 57,4 & 98 & 62,8 \\
& Female & 38 & 34,9 & 20 & 42,6 & 58 & 37,2 \\
Age & Between 23-30 years & 32 & 29,4 & 24 & 51,1 & 56 & 35,9 \\
& Between 31-40 years & 68 & 62,4 & 23 & 48,9 & 91 & 58,3 \\
Marital Status & 41 years and older & 9 & 8,3 & - & - & 9 & 5,8 \\
& Married & 78 & 71,6 & 32 & 68,1 & 110 & 70,5 \\
& Single & 31 & 28,4 & 15 & 31,9 & 46 & 29,5 \\
Working Period & Between 1-5 years & 41 & 37,6 & 21 & 44,7 & 62 & 39,7 \\
& Between 6-10 years & 37 & 33,9 & 21 & 44,7 & 58 & 37,2 \\
\multirow{2}{*}{ Educational Level } & Between 11-15 years & 18 & 16,5 & 4 & 8,5 & 22 & 14,1 \\
of the School & 16 years and over & 13 & 11,9 & 1 & 2,1 & 14 & 9,0 \\
\multirow{2}{*}{ Educational Status } & Secondary School & 74 & 67,9 & 34 & 72,3 & 108 & 69,2 \\
\multicolumn{1}{c}{ Total } & High School & 35 & 32,1 & 13 & 27,7 & 48 & 30,8 \\
& Bachelor's Degree & 101 & 92,7 & 46 & 97,9 & 147 & 94,2 \\
& Postgraduate Degree & 8 & 7,3 & 1 & 2,1 & 9 & 5,8 \\
& & 109 & 69,9 & 47 & 30,1 & 156 & 100 \\
\hline
\end{tabular}


According to the results in Table 1, 98 (62.8\%) of physical education teachers were male, $58(37.2 \%)$ were female, $91(58.3 \%)$ of the teachers were between 31-40 years old, $110(70.5 \%)$ of them were married. It was found that 62 $(39.7 \%)$ of the teachers had $1-5$ years working period, $108(69.2 \%)$ of them worked in secondary schools and 147 (94.2\%) of them bachelor graduates.

\subsection{Data Collection Tool}

As the data collection tool the "Physical Education Teachers' Use of Teaching Styles and Perceptions of Styles Questionaire", developed by Kulinna and Cothran (2003) and adapted to Turkish by Ince and Hunuk (2010), was used in the research. The internal consistency of the scale ranged between .86 and .95 in the value perception dimension of each style, 11 factors explained $86.3 \%$ of the total variance, and factor loadings ranged between .79 and .89 (Ince and Hunuk, 2010). There are 11 different teaching styles in the scale (Command Style-A, Practice Style-B, Reciprocal Style-C, Self-Check Style-D, Inclusion Style-E, Guided Discovery Style-F, Convergent Discovery Style-G, Divergent Production Style-H, Learner's Individual Designed Program Style-I, Learner Initiated Style-J, Self-Teaching Style-K). In the scale, there are 4 questions related to each style scenario and these questions are evaluated with a 5-point Likert-type scale ( $1=$ None, $2=$ Rarely, $3=$ Occasionally, $4=$ Often, $5=$ Always $)$. The questionnaire includes 4 questions related to 11 teaching styles. The first questions related to teaching styles determine the level of teacher's use of the relevant style. This question is analyzed in two ways: firstly, it is evaluated by taking the average value on the 5-point likert scale and secondly, not using those styles who answer "None"; "Rarely, Occasionally, Often and Always is the style of "user". Other questions (second, third, and fourth) are related to value perceptions of styles. The second question is about the style's "fun" value perception, the third question is about the "learning" value perception of the style, and the fourth question is related to the style's "motivation" value perception (minimum 1, maximum 5). The value obtained from the sum of these three questions (minimum 3, maximum 15) shows the teacher's "value perception" level about the related style (Ince and Hunuk, 2010; Sarac and Mustu, 2013; Cengiz and Serbes, 2014).

\subsection{Analysis of Data}

The answers of the physical education teachers to the Teaching Styles Value Perceptions Questionnaire were analyzed and the arithmetic mean and standard deviation data related to the teachers' teaching styles preferences, perceptions of value, entertainment, learning and motivation value perceptions were presented in meaningful tables. Statistical differences between teaching style preferences, value perceptions, fun, learning and motivation value perception scores of physical education teachers according to their working status in public and private schools independent t-test and variance analysis tests were used for repeated measures. The meaningfulness level was adopted as $\alpha=0.05$.

\section{Results}

In Table 2 below, a comparison of the averages of teaching styles and value perceptions of physical education teachers working in public and private schools.

Considering the findings in Table 2, it was determined that physical education teachers generally prefer command, practice and reciprocal styles, teachers working in private schools use command and practice styles more than those working in public schools, while reciprocal style is used more often than teachers in private schools. It was also specified that physical education teachers preferred learner's individual designed program, learner initiated and self-teaching styles less, and those in public schools used them more than teachers in private schools.

When physical education teachers' perceptions of value were examined, it was found that teachers perceived teaching styles through presentation more valuable than teaching styles through invention. Physical education teachers working in public schools perceived convergent discovery, learner initiated and self-teaching styles more valuable than teachers in private schools. 
Table 2. Comparison of Teaching Styles and Value Perceptions of Physical Education Teachers Working in Public and Private Schools

\begin{tabular}{|c|c|c|c|c|c|c|c|c|}
\hline \multirow{2}{*}{ Teaching Styles } & \multirow[t]{2}{*}{ Type of School } & \multicolumn{4}{|c|}{ Use the Style $^{1}$} & \multicolumn{3}{|c|}{ Style Value Perception ${ }^{2}$} \\
\hline & & $\mathbf{n}$ & $\mathbf{X}$ & SS & $\mathbf{t}$ & $\mathbf{X}$ & SS & $\mathbf{t}$ \\
\hline \multirow{2}{*}{ Command Styles (A) } & Public School & 109 & 3,97 & 1,06 & \multirow{2}{*}{$-0,644$} & 11,90 & 2,35 & \multirow{2}{*}{0,768} \\
\hline & Private School & 47 & 4,08 & 0,82 & & 11,61 & 1,67 & \\
\hline \multirow{2}{*}{ Practice Styles (B) } & Public School & 109 & 3,80 & 1,26 & \multirow{2}{*}{$-0,217$} & 11,53 & 2,71 & \multirow{2}{*}{$-1,662$} \\
\hline & Private School & 47 & 3,85 & 0,83 & & 12,25 & 1,88 & \\
\hline \multirow{2}{*}{ Reciprocal Styles (C) } & Public School & 109 & 3,56 & 1,12 & \multirow{2}{*}{1,174} & 11,10 & 2,61 & \multirow{2}{*}{0,705} \\
\hline & Private School & 47 & 3,34 & 1,08 & & 10,78 & 2,38 & \\
\hline \multirow{2}{*}{ Self-Check Styles (D) } & Public School & 109 & 3,43 & 1,23 & \multirow{2}{*}{0,430} & 10,65 & 3,05 & \multirow{2}{*}{0,657} \\
\hline & Private School & 47 & 3,34 & 1,14 & & 10,31 & 2,48 & \\
\hline \multirow{2}{*}{ Inclusion Styles (E) } & Public School & 109 & 3,55 & 1,14 & \multirow{2}{*}{0,878} & 10,87 & 2,76 & \multirow{2}{*}{$-0,049$} \\
\hline & Private School & 47 & 3,38 & 0,96 & & 10,89 & 2,10 & \\
\hline \multirow{2}{*}{ Guided Discovery Styles (F) } & Public School & 109 & 3,37 & 1,16 & \multirow{2}{*}{0,070} & 11,10 & 2,76 & \multirow{2}{*}{1,122} \\
\hline & Private School & 47 & 3,36 & 1,20 & & 10,55 & 2,86 & \\
\hline Convergent Discovery Styles & Public School & 109 & 3,48 & 1,08 & \multirow{2}{*}{1,768} & 10,98 & 2,55 & \multirow{2}{*}{$2,249 *$} \\
\hline$(\mathrm{G})$ & Private School & 47 & 3,14 & 1,12 & & 9,93 & 2,89 & \\
\hline Divergent Production Styles & Public School & 109 & 3,43 & 1,11 & \multirow{2}{*}{0,714} & 10,93 & 2,77 & \multirow{2}{*}{0,747} \\
\hline$(\mathrm{H})$ & Private School & 47 & 3,29 & 0,95 & & 10,57 & 2,75 & \\
\hline Learner's Individual Designed & Public School & 109 & 3,38 & 1,29 & \multirow{2}{*}{0,405} & 10,65 & 2,97 & \multirow{2}{*}{1,027} \\
\hline Program Styles (I) & Private School & 47 & 3,29 & 1,10 & & 10,12 & 2,79 & \\
\hline \multirow{2}{*}{ Learner Initiated Styles (J) } & Public School & 109 & 3,25 & 1,33 & \multirow{2}{*}{$2,152 *$} & 10,90 & 3,05 & \multirow{2}{*}{$2,861 *$} \\
\hline & Private School & 47 & 2,76 & 1,23 & & 9,27 & 3,72 & \\
\hline \multirow{2}{*}{ Self-Teaching Styles (K) } & Public School & 109 & 3,17 & 1,34 & \multirow{2}{*}{$3,153 *$} & 10,48 & 3,42 & $4,023 *$ \\
\hline & Private School & 47 & 2,42 & 1,39 & & 8,02 & 3,70 & ,, $0 \mathrm{dJ}$ \\
\hline
\end{tabular}

$* \mathrm{p}<0,05$

${ }^{1}$ The minimum value that can be obtained is 1 and the maximum value is 5 .

${ }^{2}$ The minimum value that can be obtained is 3 and the maximum value is 15 .

Table 3 presents the average value perceptions of physical education teachers in the dimensions of fun, learning and motivation for each style.

According to the results of variance analysis for repetitive measurements, physical education teachers' teaching styles according to the public and private schools there was a statistically meaningful difference between the fun value perceptions $\left(\mathrm{F}_{(1,154)}=9.381, \mathrm{p}=0.003\right)$, learning value perceptions $\left(\mathrm{F}_{(1,154)}=9,490, \mathrm{p}=0.002\right)$ and motivation value perceptions $(\mathrm{F}((1,154)=15,178, \mathrm{p}=0,000)(\mathrm{p}<0.05)$.

It has been specified that physical education teachers perceive the command and practice styles, which are among the teaching styles, more important in the perceptions of the value perceptions of each style in providing fun, learning and motivation to the students. It is seen that physical education teachers working in public schools give more importance to the command style in terms of having fun, learning and motivation value perception than teachers working in private schools. On the other hand, it was determined that physical education teachers who work in private schools give more importance to practice style than teachers working in public schools in terms of having fun, learning and motivation value perception dimension. 
Table 3. Physical Education Teachers' Perceptions of Value in the Dimensions of Each Style Providing Fun, Learning and Motivation to Students

\begin{tabular}{|c|c|c|c|c|c|c|c|c|}
\hline \multirow{2}{*}{ Teaching Styles } & \multicolumn{2}{|l|}{ Type of School } & \multicolumn{2}{|c|}{ Fun ${ }^{1}$} & \multicolumn{2}{|c|}{ Learning $^{1}$} & \multicolumn{2}{|c|}{ Motivation $^{1}$} \\
\hline & & $\mathbf{n}$ & $\mathbf{X}$ & SS & $\mathbf{X}$ & SS & $\mathbf{X}$ & SS \\
\hline \multirow{2}{*}{ Command Styles (A) } & Public School & 109 & 3,88 & 1,05 & 3,94 & 0,96 & 4,08 & 0,95 \\
\hline & Private School & 47 & 3,63 & 0,81 & 3,91 & 0,77 & 4,06 & 0,79 \\
\hline \multirow{2}{*}{ Practice Styles (B) } & Public School & 109 & 3,83 & 1,04 & 3,83 & 1,07 & 3,86 & 1,01 \\
\hline & Private School & 47 & 4,00 & 0,72 & 4,08 & 0,71 & 4,17 & 0,91 \\
\hline \multirow{2}{*}{ Reciprocal Styles (C) } & Public School & 109 & 3,67 & 0,94 & 3,70 & 1,11 & 3,71 & 0,99 \\
\hline & Private School & 47 & 3,59 & 0,77 & 3,48 & 0,95 & 3,70 & 1,06 \\
\hline \multirow{2}{*}{ Self-Check Styles (D) } & Public Scho & 109 & 3,43 & 1,24 & 3,65 & 1,16 & 3,56 & 1,12 \\
\hline & Private School & 47 & 3,34 & 0,93 & 3,48 & 0,88 & 3,48 & 0,95 \\
\hline \multirow{2}{*}{ Inclusion Styles (E) } & Public Scho & 109 & 3,49 & 1,17 & 3,67 & 1,05 & 3,69 & 1,02 \\
\hline & Private Scho & 47 & 3,68 & 0,72 & 3,48 & 0,88 & 3,72 & 0,87 \\
\hline \multirow{2}{*}{ Guided Discovery Styles (F) } & Public School & 109 & 3,68 & 1,04 & 3,66 & 1,00 & 3,74 & 1,06 \\
\hline & Private School & 47 & 3,46 & 0,95 & 3,51 & 1,01 & 3,57 & 1,21 \\
\hline \multirow{2}{*}{ Convergent Discovery Styles (G) } & Public Scho & 109 & 3,65 & 0,99 & 3,70 & 0,98 & 3,62 & 1,02 \\
\hline & Private School & 47 & 3,27 & 1,03 & 3,34 & 1,08 & 3,31 & 1,06 \\
\hline \multirow{2}{*}{ Divergent Production Styles (H) } & Public Scho & 109 & 3,56 & 1,03 & 3,68 & 1,03 & 3,67 & 1,03 \\
\hline & Private Scho & 47 & 3,40 & 0,94 & 3,57 & 1,03 & 3,59 & 1,03 \\
\hline \multirow{2}{*}{$\begin{array}{l}\text { Learner's Individual Designed } \\
\text { Program Styles (I) }\end{array}$} & Public School & 109 & 3,44 & 1,09 & 3,53 & 1,13 & 3,66 & 1,16 \\
\hline & Private School & 47 & 3,40 & 0,94 & 3,36 & 1,05 & 3,36 & 1,13 \\
\hline \multirow{2}{*}{ Learner Initiated Styles $(\mathrm{J})$} & Public Scho & 109 & 3,49 & 1,15 & 3,71 & 1,21 & 3,69 & 1,10 \\
\hline & Private School & 47 & 3,02 & 1,29 & 3,08 & 1,24 & 3,17 & 1,37 \\
\hline \multirow{2}{*}{ Self-Teaching Styles (K) } & Public School & 109 & 3,44 & 1,28 & 3,43 & 1,20 & 3,60 & 1,28 \\
\hline & Private School & 47 & 2,46 & 1,26 & 2,76 & 1,33 & 2,78 & 1,44 \\
\hline
\end{tabular}

${ }^{1}$ The minimum value that can be obtained is 1 and the maximum value is 5 .

\section{Discussion and Conclusion}

According to the results of the research in Table 2, it has been determined that command, practice and reciprocal styles which are included in the expository teaching styles by physical education teachers are preferred more and teaching styles through the discovery are used less. Command and practice styles are used by teachers working in private schools and reciprocal style is used more by teachers in public schools. These results can be interpreted as the fact that physical education teachers consider teacher-centered teaching styles, which require less labor, time and cost, contribute to the development of the students to a lesser extent, and are more important in the course of instruction. It can also be said that physical education teachers are under the influence of teacher-centered methods they see from their teachers throughout their education processes. Hein et al. (2012) found that physical education teachers use teacher-centered teaching styles in Spain, Hungary, Estonia, Lithuania and Latvia. Stephanou and Tsapakidou (2007) found that physical education teachers in Greece prefer teacher-centered styles more. Jaakkola and Watt (2011) determined that physical education teachers preferred teacher-centered styles over student-centered styles in Finland. Macfadyen and Campbell (2005) found that secondary school physical education teachers use teacher-centered style in England. Yildiz and Kangalgil (2014) determined that students limit their development in the course of the physical education teachers in Turkey most command, practice and reciprocal styles they use. Aktop and Karahan (2012) determined that physical education teachers in Turkey mostly use teacher-centered teaching styles. Ince and Hunuk (2010) found that the physical education teachers intensively use and valued teacher centered styles. Aggez (2015), Ertan and Cicek (2003) and Demirhan et al. (2008) determined that physical education teachers more intensively use of the command and practice styles in Turkey. Cengiz and Serbes (2014) and Sarac and Mustu (2013) found that preservice physical education teachers mostly prefer command and practice teaching styles. However, they found that preservice physical education teachers use teacher-centered styles much more. Parker and Curtner-Smith (2012) determined that preservice physical education teachers mostly used practice style in various sports activities, rarely used command style, reciprocal style and learner-centered styles, and never used self-check and inclusion styles.

In addition to this, it can also be thought that physical education teachers in public schools tend to be more prone to learner-centered styles than teachers in private schools and consider important but do not apply. Morgan et al. (2005) 
found that students gave more cognitive and affective responses to reciprocal and guided discovery styles than command and practice styles in terms of competence and less performance-oriented teaching behaviors.

The results in Table 3 can be explained that physical education teachers find the command and practice styles more valuable in terms of students' fun, learning and motivation, and they carry out teacher-centered styles and lessons. In addition, it can be said that physical education teachers in public schools use the command style which has a more traditional and authoritarian structure. It can be commented that physical education teachers in private schools use practice style in the basis teacher-centered styles that allow students to practice while repeating the skills they teach. Ozlu (2014) found that in Turkey physical education teachers who are working in secondary and high school they teach more teacher-centered teaching styles and they value those styles. Ince and Hunuk (2010) determined that physical education teachers who teach student-centered styles in Turkey, they saw more effective for fun, learning and motivation and they show high values, it was also found that they use more of these styles. Syrmpas and Digelidis (2014) found that preservice physical education teachers in Greece prefer teacher-centered styles more in terms of fun, learning and motivation. Chatoupis (2010) determined that physical education teachers use teaching styles that contribute to students' psychomotor development, that is, often reproduction-based styles. Kulinna and Cothran (2003) found that physical education teachers in the United States had significantly different experiences in using and perceiving different teaching styles and that they used command and practice styles more frequently in teaching centered styles. Cothran et al. (2005) determined that physical education teachers in Portugal and Korea used teacher-centered styles more than physical education teachers in Canada, England and Australia. Curtner-Smith et al. (2001) found that physical education teachers in England mostly use command and practice styles, known as direct teaching methods. Serbes and Cengiz (2015) determined that preservice physical education teachers prefer teacher-centered styles in Turkey and have also indicated that they have shown a high value perception for this style.

Consequently, it was determined that physical education teachers in both public and private schools use teaching centered teaching styles. It is thought that it will be important to use qualitative research methods and to determine why teachers use teacher-centered styles in future researches.

\section{References}

Aggez, I. T. (2015). Teaching styles used by physical education teachers. Master's Thesis, Kirikkale University Health Sciences Institute, Kirikkale, Turkey.

Aktop, A., \& Karahan, N. (2012). Physical education's teacher views of effective teaching methods in physical education. Procedia-Social and Behavioral Sciences, 46, 1910-1913. https://doi.org/10.1016/j.sbspro.2012.05.401

Cengiz, C., \& Serbes, S. (2014). Turkish pre-service physical education teachers' self-reported use and perceptions of teaching styles. Pamukkale Journal of Sport Sciences, 5(2), 21-34.

Chatoupis, C. (2010). An analysis of spectrum research on teaching. Physical Educator, 67(4), 187-196.

Christenson, R., \& Barney, D. (2010). The spectrum of teaching styles: Style F-guided discovery. OAHPERD Journal, XLVI(2), 14-16.

Cothran, D. J., Kulinna, P. H., Banville, D., Choi, E., Amade-Escot, C., Mac Phail, A., Macdonald, D., Richard, J. F., Sarmento, P., \& Kirk, D. (2005). A cross-cultural investigation of the use of teaching styles. Research Quarterly for Exercise and Sport, 76, 193-201. https://doi.org/10.1080/02701367.2005.10599280

Curtner-Smith, M. D., Todorovich, J. R., McCaughtry, N. A., \& Lacon, S. A. (2001). Urban teachers' use of productive and reproductive teaching styles within the confines of the national curriculum for physical education. European Physical Education Review, 7(2), 177-190. https://doi.org/10.1177/1356336X010072005

Demirhan, G., Bulca, Y., Altay, F., Sahin, R., Guvenc, A., Aslan, A., Guven, B., Kangalgil, M., Hunuk, D., Koca, C., \& Acikada, C. (2008). Comparison of the views of partners regarding the physical education curriculum and it's delivery. Hacettepe Journal of Sport Sciences, 19(3), 157-180.

Ertan, H., \& Cicek, S. (2003). Student achievement evaluation approaches in elementary physical education courses in Turkey. Hacettepe University Journal of Education, 25, 76-83.

Fraenkel, J. R., Wallen, N. E., \& Hyun, H. H. (2006). How to design and evaluate research in education (8th ed.). New York: McGraw-Hill.

Hein, V., Ries, F., Pires, F., Caune, A., Emeljanovas, A., Ekler, J. H., \& Valantiniene, I. (2012). The relationship 
between teaching styles and motivation to teach among physical education teachers. Journal of Sports Science and Medicine, 11(1), 123-130.

Ince, M. L., \& Hunuk, D. (2010). Experienced physical education teachers' use and perceptions of teaching styles during the educational reform period. Education and Science, 35(157), 128-139.

Jaakkola, T., \& Watt, A. (2011). Finnish physical education teachers'self-reported use and perceptions of Mosston and Ashworth's Teaching Styles. Journal of Teaching in Physical Education, 30(3), 248-262. https://doi.org/10.1123/jtpe.30.3.248

Jenkins, J. M., Jenkins, P., Collums, A., \& Werhonig, G. (2006). Student perceptions of a conceptual physical education activity course. Physical Educator, 63(4), 210-221.

Karaagacli, M. (2005). Ogretimde yontemler ve yaklasimlar. [Methods and approaches in teaching]. Ankara, Turkey: Pelikan Publishing.

Kulinna, P. H., \& Cothran, D. J. (2003). Physical education teachers' self-reported use and perceptions of various teaching styles. Learning and Instruction, 13(6), 597-609. https://doi.org/10.1016/S0959-4752(02)00044-0

Macfadyen, T., \& Campbell, C. (2005). An investigation into the teaching styles of secondary school physical education teachers. Paper presented at the British Educational Research Association Annual Conference, University of Glamorgan, United Kingdom, 14-17 September.

Metzler, M. (2017). Instructional models in physical education (3rd ed.). New York: Routledge. https://doi.org/10.4324/9781315213521

Morgan, K., Kington, K., \& Sproule, J. (2005). Effects of different teaching styles on the teacher behaviours that influence motivational climate and pupils' motivation in physical education. European Physical Education Review, 11(3), 257-285. https://doi.org/10.1177/1356336X05056651

Mosston, M., \& Ashworth, S. (2002). Teaching physical education (5th ed.). San Francisco: Benjamin Cummings.

Ozlu, K. (2014). The teaching styles used by physical educaton teachers working at secondary and high schools and their value perceptions of these styles. Master's Thesis, Amasya University Social Sciences Institute, Amasya, Turkey.

Pangrazi, P. R. (2007). Dynamic physical education for elementary school children. San Francisco: Pearson Benjamin Cummings.

Papaioannou A., \& Kouli O. (1999). The effect of task structure, perceived motivational climate and goal orientations on students' task involvement and anxiety, Journal of Applied Sport Psychology, 11(1), 51-71. https://doi.org/10.1080/10413209908402950

Parker, M., \& Curtner-Smith, M. (2012). Preservice teachers' use of production and reproduction teaching styles within multi-activity and sport education units. European Physical Education Review, 18(1), 127-143. https://doi.org/10.1177/1356336X11430655

Sanchez, B., Byra, M., \& Wallhead, T. L. (2012). Students' perceptions of the command, practice, and inclusion styles of teaching. Physical Education and Sport Pedagogy, 17(3), 317-330. https://doi.org/10.1080/17408989.2012.690864

Sarac, L., \& Mustu, E. (2013). Öğretmen adaylarının beden eğitimi öğretim stillerini kullanım düzeyleri ile stillere ilişkin değer algılarının incelenmesi. [Examination of pre-service teachers' level of use of physical education teaching styles and their perceptions about value]. Pamukkale Journal of Sport Sciences, 4(2), 112-124.

Serbes, S., \& Cengiz, C. (2015). Pre-service classroom and physical education teachers' teaching styles preferences and perceptions of teaching styles. Bartin University Journal of Faculty of Education, 4(1), 101-114.

Simsek, A. (2012). Arastirma modelleri. [Research models]. In Simsek, A. (Ed.), Sosyal bilimlerde arastirma yontemleri. [Research models in social sciences]. Eskisehir, Turkey: Anadolu University Publishing.

Stephanou, G., \& Tsapakidou, A. (2007). Teachers' teaching styles and self-efficacy in physical education. International Journal of Learning, 14(8), 1-12. https://doi.org/10.18848/1447-9494/CGP/v14i08/45452

Syrmpas, I., \& Digelidis, N. (2014). Physical education student teachers' experiences with and perceptions of teaching styles. Journal of Physical Education and Sport, 14(1), 52-59.

Tamer, K., \& Pulur, A. (2001). Beden egitimi ve sporda ogretim yontemleri [Physical education and sport teaching 
methods]. Ankara, Turkey: Kozan Publishing.

Taspinar, M. (2010). Kuramdan uygulamaya ogretim ilke ve yontemleri [Principles and methods of teaching from theory to practice] (4th ed.). Ankara, Turkey: Data Publishing.

Tessier, D., Sarrazin, P., \& Ntoumanis, N. (2010). The effect of an intervention to improve newly qualified teachers' interpersonal style, students motivation and psychological need satisfaction in sport-based physical education. Contemporary Educational Psychology, 35(4), 242-253. https://doi.org/10.1016/j.cedpsych.2010.05.005

Yildiz, E., \& Kangalgil, M. (2014). The examination of physical education teacher's professional competence and ideas regarding their teaching methods. Pamukkale Journal of Sport Sciences, 5(1), 61-76. 